MS, Vol. 4, No. 2, July 2005 - Dec. 2005, pp. 49-54

ISSN 0975-3311

https:/ / doi.org/ 10.12725/ mjs.7.6

\title{
AN EVALUATION OF DIFFERENT ORGANIC MANURES AND THEIR P-ENRICHED FORMS AT DIFFERENT LEVELS OF P-FERTILIZATION USING MAIZE CROP
}

Basavarai, N.S. Hebsur, P.L. Patil and H.M. Manjunathaiah*

\section{ABSTRACT}

The results of the experiment indicated that the content and uptake of $P$ by moize was significantly enhanced with all the four sources viz., FYM, $V C, B S$ and $P M$. Increasing levels of $P$ resulted in enhanced $P$ content and $P$ uptake by maize.

The recovery of $P$ from different $P$ carriers applied to soil varied from 10-15 per cent due to conversion of available $\mathrm{P}$ to Al-P and Fe-P in acid soil and $\mathrm{Ca}-\mathrm{P}$ in alkaline soil. Therefore, there is an urgent need to improve the efficiency of added inorganic $P$ through P-enrichment of organic manures. Several research workers already indicated that addition of FYM with P-fertilizer to soil reduced P-fixation thereby increasing the efficiency of P-fertilizer. As a result it was possible to reduce the

- Department of Soil Science and Agricultural Chemistry, U.A.S., Dhanwad. 
recommended level of $P$ application to different crops. However, the techniques to increase the efficiency of inorganic $P$ fertilizer in Vertisols under irrigated condition in maize are lacking. Hence, the present study was undertaken to evaluate effect of P-enriched organics and P-levels in maize.

\section{Material and Methods}

A field experiment was conducted at Main Research Station, University of Agricultural Sciences, Dhanwad (Karnataka) on a Chromic Haplustert during Kharif seasons of 1997 and 1998 to investigate the effect of P-enriched organic manures applied to maize crop under irrigated condition.

The experiment was laid out in a split plot design which consisted of three main treatments viz., control $\left(0 \mathrm{~kg} \mathrm{P}_{2} \mathrm{O}_{5}\right.$ ha $\left.^{-1}\right), 50$ per cent of recommended dose of $\mathrm{P}$ $\left(37.5 \mathrm{~kg} \mathrm{P} 20 \mathrm{O}_{5} \mathrm{ha}^{-1}\right)$ and 100 per cent of recommended dose of $\mathrm{P}\left(75 \mathrm{~kg} \mathrm{P} \mathrm{O}_{5}\right.$ $\mathrm{ha}^{-2}$ ) and nine sub treatments viz., no organic manure, farmyard manure at 5 t ha- $a^{-1}$ vermicompost at 2 tha ${ }^{-1}$, biogas slurry at 3 t ha- and poultry manure at $2 \mathrm{tha}^{-1}$, P-enriched farmyard manure at $2.5 \mathrm{tha}^{-1}$, P-enriched vermicompost at $1 \mathrm{th} \mathrm{a}^{-1}$, P-enriched biogas slurry at $1.5 \mathrm{tha}^{-1}$ and $P$-enriched poultry manure at It ha ${ }^{-1}$. The total content of $P$ in farmyard manure (FYM), vermicompost (NC), biogas slurry (BS) and poultry manure (PM) were determined and the calculated quantity of each organic manure was faken separately and mixed well with single superphosphate to make exactly the double the quantity of phosphorus in each organic manure. Organic manures mixed with SSP were filled separately in polyethylene bags and the required quantity of water was added to each bag to maintain moist condition ( $50 \%$ of maximum water retention capacity of the manure). The bags were incubated for a period of one month by adding water to maintain uniform moisture level in the entire incubated time. After the incubation period of 30 days all these manures were dried and applied to soil. Maize (var. Deccan 103) was grown as a test crop. A basal dose of $75 \mathrm{~kg} \mathrm{~N}$ as urea, phosphorus as single surperphospate and $37.5 \mathrm{~kg} \mathrm{~K} \mathrm{O}_{2} \mathrm{O}$ as muriate of potash were applied. The characteristics of the soil of experimental site were : $\mathrm{pH} 7.2, \mathrm{EC} 0.15 \mathrm{dSm}^{-1}$, CEC $40.60 \mathrm{cmol}\left(\mathrm{p}^{+}\right) \mathrm{kg}^{-1}$ and available $P 13.2 \mathrm{~kg} \mathrm{ha}^{-1}$. At harvest soil samples were collected and analysed for $P$ by following colorimetric method using Sphectrophotometer (Jackson, 1967). Phosphorus in plants (straw + grain) at harvest was estimated following the procedure explained by Jackson (1967). Chemical composition of organic manures were $\mathrm{pH} 6.70,7.2,5.00$ and 7.10 of FYM, VC, BS and PM, respectively and phosphorus content of FYM, VC, BS and PM were $0.6,0.5,0.7$ and 1.2 , respectively. 


\section{Results and Discussion}

The perusal of the results presented in Table 1 indicate that the highest P-concentration of 0.34 per cent was observed due to the addition of 50 per cent RD-P. Application of organic manures and P-enriched organic manures significantly increased the phosphorus concentration from 0.29 to 0.34 per cent over control (0.29 per cent). This may be due to the increase in the available phosphorus in the soil and difference in the concentration of $P$ within the organic manures may be attributed to the difference in the availability of phosphorus. The highest $P$ content in maize $(0.34 \%)$ was observed due to the addition of P-enriched poultry manure as it contain the highest $P$ among the organic manures. These results are in line with the reports of Sharma and Saxena (1985) and Madhumita Das etal. (1991).

Table-1: Effect of P-enriched organic manures at different levels of P-fertilizer on phosphorus concentration (Straw + grain) (per cent) in maize at harvest

\begin{tabular}{|c|c|c|c|c|}
\hline \multirow[t]{2}{*}{ Treatment } & \multicolumn{4}{|c|}{ Pooled dato for 2 years (1997 and 98 ) } \\
\hline & $M_{0}$ & $M_{1}$ & $M_{2}$ & Mean \\
\hline$T_{1} \cdot$ Control & 0.24 & 0.25 & 0.24 & 0.25 \\
\hline$T_{2}-F Y M @ 5$ tha.' & 0.28 & 0.27 & 0.25 & 0.26 \\
\hline$T_{3}=V C @ 2+h a^{\prime}$ & 0.30 & 0.30 & 0.33 & 0.32 \\
\hline$T_{4} \cdot B S @ 3$ tho.1 & 0.32 & 0.35 & 0.35 & 0.33 \\
\hline$T_{5} \cdot P M @ 2: h a^{\prime \prime}$ & 0.34 & 0.36 & 0.31 & 0.33 \\
\hline$T_{6} \cdot P \cdot F Y M @ 2.5+h a^{-1}$ & 0.32 & 0.32 & 0.35 & 0.33 \\
\hline$T_{7} \cdot P-V C @ 1$ tha-1 & 0.33 & 0.32 & 0.36 & 0.29 \\
\hline$T_{8}-P$ - BS@ 1.5 +ha-1 & 0.31 & 0.29 & 0.30 & 0.33 \\
\hline$T_{9}-P . P M @ 1+h o^{\prime \prime}$ & 0.32 & 0.31 & 0.31 & 0.34 \\
\hline \multirow[t]{2}{*}{ Mean } & 0.26 & 0.34 & 0.33 & \\
\hline & \multicolumn{2}{|l|}{$\mathrm{S} . \mathrm{Em} \pm$} & \multicolumn{2}{|c|}{ C.Dat (5\%) } \\
\hline M & 0.001 & \multicolumn{3}{|c|}{0.004} \\
\hline T & 0.002 & & \multicolumn{2}{|c|}{$\begin{array}{l}0.005 \\
0.010\end{array}$} \\
\hline$M \times T(T$ at same level of $M)$ & 0.003 & \multicolumn{3}{|c|}{0.010} \\
\hline$M \times T$ (M at some or different level of $T)$ & 0.003 & \multicolumn{3}{|c|}{0.014} \\
\hline
\end{tabular}

FYM = Formyard monure,

$V C=$ Vermicompost, $B S=$ Biogas slurry, $P M=$ Poultry monure

$M_{0}=N_{0}$ P.fertilizer, $M_{1}=50 \%$ recommended dose of P.fertilizer $\left(37.5 \mathrm{~kg} \mathrm{P}_{2} \mathrm{O}_{5}\right.$ ha-') $), M_{2}=100 \%$ recommended dose of P.fertilizer $\left(75.0 \mathrm{~kg} \mathrm{P}_{2} \mathrm{O}_{5}\right.$ ha-1) $^{-1}$. 
The concentration of phosphorus in maize was highest $(0.36 \%)$ due to application of P-enriched PM and 50 per cent RD-P. The organic matter in the PM must have protected the applied water soluble $P$ from fixation and they must have also increased the availability of native soil P. More and Ghonsikar (1988) obtained significantly higher phosphorus content in wheat plant when single superphosphate (SSP) was applied alongwith organic manures (poultry manure, FYM and goat manure) than application of SSP alone.

Application of $P$-enriched organic manures significantly increased $P$ uptake and it was ranged from 48.20 to $57.47 \mathrm{~kg} \mathrm{ha}^{-1}$ (Table 2). Among the P-enriched organics the highest uptake of $P$ was noticed due to application of $P$-enriched poultry manure $\left(57.47 \mathrm{~kg} \mathrm{ha}^{-1}\right)$. This may be ascribed to the increase in the availability of major nutrients in the soil due to the addition of P-enriched poultry manure compared to organic manures without P-enrichment. These observations are in accordance with the reports of More and Ghonsikar (1988) and Madhumita Das et al. (1991).

\section{Table-2: Effect of P-enriched organic manures at different levels of P- fertilizer on phosphorus uptake (Straw + grain) $\left(\mathrm{kg} \mathrm{ha}^{-1}\right)$ in maize at harvest}

\begin{tabular}{|c|c|c|c|c|}
\hline \multirow[t]{2}{*}{ Treoiment } & \multicolumn{4}{|c|}{ Pooled dato for 2 years (1997 and 98) } \\
\hline & $M_{0}$ & $M_{1}$ & $\mathrm{M}_{2}$ & Meon \\
\hline$T_{1} \cdot$ Control & 33.2 & 36.5 & 34.6 & 35.7 \\
\hline$T_{2}=F Y M @ 5 t h a^{\prime}$ & 41.7 & 41.4 & 37.4 & 39.1 \\
\hline$r_{3}=v C @ 2 t h a^{-1}$ & 46.6 & 48.0 & 53.9 & 50.4 \\
\hline$T_{4} \cdot B S @ 3+h 0^{-1}$ & 51.9 & 58.1 & 57.9 & 53.5 \\
\hline$T_{5} \cdot P M @ 2$ tho.1 & 55.1 & 61.4 & 50.3 & 55.7 \\
\hline$T_{6}-P . F Y M @ 2.5$ tha- & 52.3 & 53.7 & 59.2 & 58.2 \\
\hline$T_{7} \cdot P-V C @ 1$ tho'1 & 53.6 & 55.3 & 64.4 & 43.8 \\
\hline $\mathrm{T}_{8}=\mathrm{P} . \mathrm{BS} @ 1.5$ tho.1 & 348.7 & 045.7 & 747.1 & 053.0 \\
\hline $\mathrm{T}_{Q}: P \cdot P M @ 1+h a^{-1}$ & 052.5 & 048.2 & 049.8 & 357.47 \\
\hline \multirow[t]{2}{*}{ Meon } & 38.5 & 54.5 & 55.9 & \\
\hline & \multicolumn{2}{|l|}{ S.Em \pm} & \multicolumn{2}{|c|}{ C.D of $(5 \%)$} \\
\hline$M$ & 0.120 & \multicolumn{3}{|c|}{0.333} \\
\hline $\mathrm{r}$ & 0.149 & \multicolumn{3}{|c|}{0.413} \\
\hline$M \times T(T$ at same level of $M)$ & 0.258 & \multicolumn{3}{|c|}{0.716} \\
\hline MxT (M ot some or different level of $T$ ) & 0.258 & \multicolumn{3}{|c|}{1.070} \\
\hline
\end{tabular}

$F Y M=$ Farmyord manure,

$V C=$ Vermicompost, $B S=$ Biogos sturry, $P M=$ Poultry manure

$M_{0}=$ No P-fertilizer, $M_{1}=50 \%$ recommended dose of P.fertilizer $\left(37.5 \mathrm{~kg} P_{2} \mathrm{O}_{5}\right.$ ho.1), $\mathrm{M}_{2}=100 \%$ recommended dose of P-fertilizer $\left(75.0 \mathrm{~kg} \mathrm{P}_{2} \mathrm{O}_{5} \mathrm{ho}^{\cdot 1}\right)$. 
Table-3: Effect of P-enriched organic manures on phosphorus use efficiency

\begin{tabular}{|c|c|c|c|c|}
\hline \multirow[t]{2}{*}{ Treatment } & \multicolumn{4}{|c|}{ Pooled doto for 2 years (1997 and 98 ) } \\
\hline & $M_{0}$ & $M_{1}$ & $M_{2}$ & Mean \\
\hline$T_{1} \cdot$ Control & .11 & 14 & 12 & 35 \\
\hline$T_{2}-F Y M @ 5 t h a^{\prime}$ & 27 & 42 & 28 & 56 \\
\hline$T_{3}-V C @ 2 \uparrow h a^{-1}$ & 39 & 31 & 36 & 32 \\
\hline$T_{4} \cdot B S @ 3 t h a^{-1}$ & 40 & 36 & 43 & 37 \\
\hline$T_{s}-P M @ 2$ tha: & 46 & 23 & 21 & 22 \\
\hline$T_{6}-P$-FYM@ $2.5+h a^{\prime \prime}$ & 21 & 26 & 24 & 24 \\
\hline$T_{7} \cdot P \cdot V C @ 1+h a^{\prime}$ & 23 & 31 & अ1 & 21 \\
\hline$T_{8} \cdot P \cdot 8 S @ 1.5$ tho.1 & 24 & 22 & 34 & 29 \\
\hline$T_{9} \cdot P \cdot P M @ 1$ tho' & 36 & 29 & 44 & \\
\hline Mean & 28 & 38 & 24 & \\
\hline
\end{tabular}

Application of levels of $P$-fertilizer significantly increased the uptake of $P$ by maize and highest $P$ uptake $\left(55.9 \mathrm{Kg} \mathrm{ha}^{-1}\right)$ was observed due to application of 100 per cent RD-P. This may be due to the increase in the availability of nutrients with the levels of P-fertilizer in the soil which led to more uptake of $P$ by maize. Similar observations were reported by Sharma and Saxena (1985), Singh and Brar (1985) and Subbareddy et al. (1991).

Application of P-enriched PM along with 100 per cent RD-P was found to be superior in the uptake of $P\left(64.40 \mathrm{~kg} \mathrm{ha}^{-3}\right)$ by maize during kharif. This may be due to the more availability of nutrients and the increase in yield due to combined application of various organic manures and levels of P-fertilizer which led to more uptake of P. Similar observations were reported by More and Ghonsikar (1988), Madhumita Das et al. (1991) and Dosani et al. (1999).

Applications of P-enriched poultry manure at $1+\mathrm{tha}^{-1}$ has increased its relative efficiency by 30.6 per cent over an addition of poultry manure at $2 \mathrm{th} \mathrm{h}^{-1}$ indicating superiority of super digested organic manure. Similar observations were reported by Virmani (1967). 


\section{References}

Dosani, A.A.K., Talashilkar, S.C. and Mehta, V.B., 1999, J. Indian Soc. Soll Sci., 47:166-169.

Madhumita Das, M., Singh, B.P. Ram, M. And Prasad, R.N.,1991, Indian J. Agri. Sci., 61 (6):383-388.

More, S.D. and Ghonsikar, C.P., 1988, J. Indian Soc. Soil Sci. 36:372-374.

Sharma, J.P. and Saxean, S.N., 1985, J. Indian Soc. Soil Sci., 33:561-567.

Singh, R.P. and Brar, S.P.S., 1985, J. Punjab Agri. Univ., 22:243.252.

Subbareddy, G., Venkateshwarulu, B., Vittal, K.P.R. and Sankar, G.R., 1991, Indian J. Agric. Sci., $61: 551.557$.

Virmani, S.M., 1967, Indian J. Agric. Sci. 37:302-307. 